\title{
4
}

\section{Fascism and Architecture}

\author{
There has never been an epoch that did not feel itself \\ to be 'modern' in the sense of eccentric, and did not believe itself \\ to be standing directly before the abyss. \\ -Benjamin (Arcades, [S1a, 4], 545)
}

This chapter traces the battles for national hegemony fought between key architectural movements and styles, which most notably pitted the supporters of Novecento and Gruppo 7 against their opponents, and the supporters of rationalism ${ }^{1}$ against those of monumentalism. These struggles shaped the development of Fascist and Italian architecture over two decades, peaking during the first half of the 1930s, and they displayed clear similarities with the debates on the novel.

Following the trajectory delineated so far, our initial hypothesis is as follows: the novel—understood by writers, publishers and intellectuals as a discursive practice connected to various degrees of realism as well as to forms of aesthetic rationalization and narrative construction-and theorizations about rationalist architecture - the project forming the basis for the design of the new collective space for the individual-possess several 
points of convergence both at a theoretical-aesthetic and at a structural level which revolve around a set of principles. Both endeavours reinforced the collective ethos of individual experience by claiming a strong moral imperative as foundational to any artistic expression; they both also promoted a desire for construction, to be realized through a process of rationalization of aesthetic forms, advocating, respectively, the need for a simplified narrative and architectural structures anchored to their 'contextual' realities (Etlin 1991, 255). As catalysts for the regime's cultural modernity and the creation of a State art, these projects not only exerted a strong internationalizing influence on national culture, but they also strengthened the national tradition at both elite and popular levels.

As with the novel, the debate on architecture played out mostly in journals of diverse orientations, and through public interventions by architects, politicians, intellectuals and even by Mussolini himself, and had as its primary aim the theorization and construction of a modern cultural and artistic infrastructure through which to initiate a process of modernization of the public sphere. The aesthetic urgency of reconstructing the novel intersected with the equally pressing need for rationalist architecture to theorize the discipline. Unlike the Italian novel, which did not reach a large audience and often remained a matter of abstract discussion, the architectural undertaking had a distinctly practical side, was visible in various forms across the whole country, was often statesponsored and followed a trajectory which clearly mirrored the rise and fall of the regime itself and of its consensus. ${ }^{2}$ Finally, architecture is not only a matter of space and design, but its language has a visual component, which the novel, traditionally, lacks.

\section{The Total Work of Art}

The total work of art can be broadly defined as a synthetic work, which aspires to integrate all its parts into a coherent whole, and dates back to the nineteenth century, with the Wagnerian Gesamtkunstwerk, which implied the reunification of all arts. ${ }^{3}$ In many ways the Fascist system of the arts was constructed along similar lines, privileging interdisciplinary intersections between different artistic and aesthetic fields. ${ }^{4}$ 
The total work of art was another notion, which had been at the centre of avant-garde artistic debate since the beginning of the twentieth century. It was vocally revived as an aesthetic and political concept by Filippo Tommaso Marinetti himself in his strenuous attempts to make Futurism the official State art, chiefly through the 1930s Manifestos of Futurist Architecture, which included Enrico 5 Prampolini's idea of totalizing architecture, and through Angiolo Mazzoni's ${ }^{6}$ work as an employee of the regime in the Ministero delle Comunicazioni (Ministry of Communication), where he designed and signed off on projects for train stations and post offices from Agrigento to Bolzano. ${ }^{7}$ In a political regime with totalitarian aspirations and an aesthetic regime seeking to rationalize structures in order to adhere to the real, Marinetti's desire for a total art along neo-Wagnerian lines was realized through a combination of old and new, erudite ${ }^{8}$ and popular, ${ }^{9}$ through a rhetoric and a type of composition which avoided the ornamental in order to distil the essence of a new society with a distinctive political ambition. ${ }^{10} \mathrm{~A}$ total and totalizing ${ }^{11}$ art would allow the coexistence of many artistic and political drives: the Futurism of the 1930s, with all its State commissions and its participation in Biennales, ${ }^{12}$ Triennales, Quadriennales; the multifaceted intermedial strength of Fortunato Depero ${ }^{13}$ and Bruno Munari ${ }^{14}$; the attempt at the twentieth-century modernization of Milan by Giovanni Muzio; the architectural renewal through the social experiments of the Gruppo 7 and later the architects Banfi, Belgioioso, Peressutti and Rogers (BBPR); the rationalization of matter and line in the sculpture of Thayaht, ${ }^{15}$ RAM $^{16}$ and Arturo Martini ${ }^{17}$; the bourgeois realism of Alberto Moravia ${ }^{18}$; the anti-bourgeois realism of Vittorini ${ }^{19}$; the return to rural realism with Corrado Alvaro, ${ }^{20}$ all side by side with the mixing of the arts practised by the Bolshevik Immaginists ${ }^{21}$ and the Bragaglia brothers, together with the cosmic experimentations of Fillìa and Prampolini. ${ }^{22}$

The new Fascist order required a new aesthetic order of discourse, which could express the collective subject and the consistency of the real and which would be driven by an ethical imperative; this is what underlines the architectural projects by State official and architect Angiolo Mazzoni. Through its many manifestations and embodiments spanning the visual arts, advertising, cinema and theatre-and in our case, literature and architecture - the total work of art also found fertile ground in 
the social and aesthetic discourse upheld by the dictatorship since, as Roberts puts it: 'These projects expressed a common will to recover the lost public function of art, a will that pointed beyond the aesthetic revolutions of the avant-gardes to political revolutions as the promise of a complete reunion of art and life' $(2011,2) .{ }^{23}$ In other words, creating a total work of art was the aim of every dictatorship, for it brought together all arts, all corners of the social sphere(s) in a concerted attempt to become $\operatorname{modern}^{24}$ and, in so doing, functionally integral to their very same existence (Roberts 2011, 5). The arts seem to move along an arc, which Elena Pontiggia has described as a 'persistent will to construct [...] a proactive and affirmative energy' to modernize $(1990,7)$. The new Fascist order required a new aesthetic order of discourse, which could express the collective subject and the consistency of the real, and would be driven by an ethical imperative. Out of this cultural renewal will emerge forms equal to the task of creating beauty in the musical, plastic, theatrical and literary arts.

\section{State Art: The Struggle for Supremacy}

In his De re aedificatoria (1443-1445), Leon Battista Alberti stated that architecture was one of the greatest of the arts because it had two souls: a practical one and a theoretical one (Prologue, 3). This alternation between the practical and theoretical sides of architecture to a large extent determined its role and position within the cultural and political Italian landscape of the inter-war period. It is precisely this Janus-like face of architecture that has shaped its history and, in the context of our study, its impact on the debates on State art, both from a political and from an aesthetic perspective. Simply put, architecture was able to contribute to the theoretical debate on the arts and power, while also showcasing its practical results and thus becoming visible to the public eye. In his Dialoghi with Emil Ludwig, held daily from the end of March to the beginning of April 1932, Mussolini himself notoriously declared that '[i] n my judgement, the greatest of all the arts [...] is architecture, because it encompasses everything', covering the public sphere as much as it does the personal sphere of the individual (Ludwig, Colloqui con Mussolini, 201 cited in Nicoloso 2008, 81). ${ }^{25}$ Up until the mid-1930s, architecture 
embodied the Fascist revolution because it not only created a collective space for the individual, but also theorized the way in which such space had to be occupied. This is shown, for example, most forcefully by the Casa del fascio ${ }^{26}$ by Giuseppe Terragni (1904-1943) built in Como in 1936, Florence train station ${ }^{27}$ (1936) by the Gruppo Toscano led by Giovanni Michelucci, the Città Universitaria La Sapienza ${ }^{28}$ in Rome (1935), which brought together the most distinguished architects of the time (Giò Ponti, Terragni, Piacentini, Pagano to name a few), as well as numerous stadia (the Foro Italico ${ }^{29}$ by Enrico Del Debbio or the Stadio Giovanni Berta ${ }^{30}$ by Pier Luigi Nervi) and post offices, a residential complex designed by Mazzoni as a seaside holiday camp for the children of industrial workers ${ }^{31}$ (Colonia Rosa Maltoni Mussolini), new corporativist cities (Littoria-Latina, 1932, Sabaudia, 1934, Tresigallo, 1934), and new working class neighbourhoods ${ }^{32}$ (Rebbio, Como, 1938) constructed throughout the 1930s (see Chap. 7). ${ }^{33}$ The year of the opening of the Casa del fascio in Como, with its Bauhaus-like translucent and transparent volumes and geometrical intersections, only marked the climax of a long-term struggle to determine which artistic movement would become the official arte di Stato and fly the banners of morality and construction..$^{34}$ By 1936, the history of experimental/rationalist architecture was nonetheless practically over. Conversely, the patron of Novecento, Margherita Sarfatti, vanished from the art scene with her last appearance on the occasion of the proclamation of the Italian Empire on 6 May 1936. 1936 also meant the end of the battles for hegemony amongst architects, with Rome-based architect Marcello Piacentini now leading the way towards $s^{35}$ monumentalism, and the rationalist movement marginalized after leaving its signature on the history of Italian architecture. ${ }^{36}$

\section{Towards an Architectural Project}

From Giovanni Muzio's ${ }^{37}$ architectural experiments in Milan resulting in the controversially modern house, the Ca' Brutta ${ }^{38}$ and the works of the Novecento architects in the early 1920s, through to the late 1920s with the theses of Gruppo 7 on architecture, and into the early 1930s with Marinetti's polemical outbursts, one can see a concerted effort at recon- 
figuring aesthetics, politics and society as a total work of art in a rather obvious fashion as far as architecture was concerned. As architectural scholar Dennis Doordan has observed: 'the development of modern architecture in Italy should be viewed as the result of the interaction of three architectural movements: Futurism, Novecentism, and Rationalism' $(1988,4)$. Despite the ongoing battles between the other two movements, Muzio and the Novecentisti remained a constant presence during the Ventennio, with notable buildings which changed the urban and cultural profile of Milan (see, for instance, Maulsby 2014, 133-60, on the planning of the Palazzo del Popolo d'Italia, 1938-1942). ${ }^{39}$ In this respect, these architectural expressions of the early 1920s are in line with Sarfatti's Novecento programme outlined on 11 January 1920 in Contro tutti $i$ ritorni in pittura ${ }^{40}$ : Manifesto futurista, signed by Leonardo Dudreville, Achille Funi, Luigi Russolo and Mario Sironi, ${ }^{41}$ and published in Milan (for the role of Sarfatti in the debates on the arte di Stato, see Chap. 2 and Fagone 1982, 45). ${ }^{42}$ Like Muzio, these artists grouped around Margherita Sarfatti rejected the return to classicism championed by the Valori plastici movement, and they too stood at a crossroads between tradition and modernity without ever conclusively choosing one over the other but aspiring to find a new aesthetic paradigm which could guarantee a hegemonic position within the construction of State art. ${ }^{43}$ Contrary to Sarfatti however, who was ideologically close to Mussolini's political programme, in Muzio's works the principal drive is explicitly stylistic, and not political: namely, the will to express the syntactical renewal of architectural language by drawing together traditional geometrical patterns in contrasting, alternating fashions (Kirk 2005, 69-70; Etlin 1991, 174-76). For both of them, one of the key aesthetic principles guiding their artistic practices was the idea of synthesis as construction and not as 'simultaneity of forces' as for the Futurists (Pontiggia 2003, 14-19; Fossati 1972, 27-33).

At the end of WWI, young Giovanni Muzio returned from the front line in Veneto to his native Milan, after having spent time in France, England and Germany in order to acquire some experience with foreign architectural traditions. His architectural mission was always that of bringing together different traditions under the overarching Italian one (this was also the reason for his prolonged success as one of Italy's leading 
architects). Muzio established his own studio in Milan, with other designers and architects who gained significant prominence in the Italian cultural sphere during the Ventennio: Giò Ponti, Emilio Lancia and Giuseppe de Finetti together with Mino Fiocchi, Gigiotti Zanini, Alpago Novello, Paolo Mezzanotte and Vittorio Pizzigoni, all members of the Gruppo Novecento, which, as an architectural movement, was also involved in debates about the urban development of the city (Maulsby 2014, 140-46). Muzio and these others aspired to reposition Italian architecture as a national project at the forefront of the European tradition, thereby signalling one of the most distinctive traits of relationship between aesthetic and political tensions during the 20 years to follow.

Muzio's breakthrough was the thousand-unit development at the corner of the Via della Moscova, a modern apartment block intended for the Milanese bourgeoisie. ${ }^{44}$ The Ca' Brutta consisted of seven floors divided into three horizontal zones, and it was the first house in the city to include an underground car park and a central heating system. In order to break the monotony of his Novecento design and the squareness of his planimetry, Muzio varied the patterns of the windows so that everyone could easily recognize his or her own flat. The Ca' Brutta's façade (made of seventeen individual façades) is severe but has no hierarchical organization, and there are only subtle variations in the repetition of similar patterns: the space has clearly been transformed from the house of the individual to the house(s) of the collective, and such a shift occurred thanks to a new aesthetic organization (Isastia and Pierini 2017, 478). It was an ideal example of modernity and tradition: where modernity was embodied in the linear, geometrical construction of the building and of its series of windows, and tradition was guaranteed by the attachment to both the Italian and the classical tradition. For example, the house is divided into two blocks which are joined together by an archway where a 'severe Palladian motif of an arcuated center bay framing the view of the narrow street and flanked by smaller trabeated bays recalls Vasari's use of a similar device for the Uffizi in Florence' (Doordan 1988, 32). Muzio's use of a reinforced concrete frame, of pillars, of cantilevered bays, and of an alternation of squares and archwindows gives the building an imposing aura over Via Moscova. The Ca' Brutta received at best a lukewarm reception, but its clear and linear geometry became a symbol of an era to come. 
Symbolically therefore, its monumental shape stands at the crossroads of the Novecento movement and of what would become rationalism in architecture and Futurism in art as far as the interplay between lines, geometry and volumes, as well as the need to modernize the public space of the individual, were concerned. ${ }^{45}$

What is particularly important to our argument is that the landmark $\mathrm{Ca}$ 'Brutta and Muzio's use of neoclassical, neo-Palladian motifs, along with his reclaiming of the straight line in a metaphysical and vertical perspective, were the first moves in a process of aesthetic rationalization, which was meant to mark a clear break with the eclecticism of the Umbertine style, with the goal of changing the very essence of urban living. Muzio wanted to create a modern palazzo which could retain the classically composed elegance of traditional architecture in a way not too dissimilar from the prosa d'arte (see Chap. 3, pp. 37-40). In this respect, Etlin has described the Ca' Brutta as an 'encyclopaedic' building with a 'fragmentary composition', a composition which achieves unity through a fragmentary compositional pattern but which remains subjective in its compositional order $(1991,184)$. The Ca' Brutta is indeed fragmentary, in the same way that the prosa d'arte was: both lacked that unity which could have ensured a more neutral presence within the urban fabric, but both aspired to a return to order based on classically composed formulations. Together with Muzio, Giuseppe De Finetti's Milanese Casa della Meridiana (Sundial House, 1924-1925) is another example of 'variation' within traditional forms (Isastia and Pierini 2017, 478). De Finetti had studied with Adolf Loos in Vienna and in 1934 published his translation of 'Ornament is crime' in Casabella. ${ }^{46}$ The Casa della Meridiana recalled Loos' 1912 Scheu House in Vienna and, just like the Ca' Brutta with its garages, experimented with modernity by replacing the traditional staircase with an elevator. Even more, the geometry of the façades and the simple lines of the windows were ideal precursors to Gruppo 7's claim to functionality. De Finetti opted for mural architecture, or for continuity between the friezes and the patterns which run across the facade of the house. The only criminal concession could be found in the pillars on the first floor balcony.

As Doordan argues: 'the Novecento movement rejected the idea that architecture should be the result of either the personal whim of the 
designer or the product of narrowly defined technological considerations'; as Borgese hoped regarding the novel, the 'tempo di edificare' (time to build) had arrived $(1988,30)$, since 'Muzioss appreciation of the Italian tradition in building [...] included a tectonic appreciation of Italian architecture as a type of mural architecture' $(1988,33)$. The Novecento movement in architecture, as in the other arts, was strongly connected to the national tradition and the Novecento architects understood and interpreted muralism as a return to order in so far as it was a return to tradition as a repertoire of composed forms which could call for a straightforward interpretation of the 'real'. The Novecentisti did not seek to reinvent tradition, but rather to reshape it in view of a widespread theoretical drive towards rationalization, which translated in social terms into an equally powerful drive towards the modernization of the social sphere through functional living and building. In essence, the Vasari-like courtyard, the Palladian arch, the golden decorative patterns on the doorbells, and the overall 'Renaissance tradition of linear surface patterning' of the Ca' Brutta are homages to the national architectural tradition, which nevertheless needed to be standardized to become modern and thus be able to transform the urban space (Etlin 1991, 185). We could conclude that the Ca' Brutta is fragmentary in conception, but aspires to be an example of a new way for the individual to inhabit collectively the public space. In this respect, it sits squarely between tradition and modernity, in a way that resembles the trajectory of the novel in the 1920s.

The dialectical clashes between modernity, modernization, national tradition and internationalization in architecture could not be fully comprehended without making a reference to Futurism. By 1914, Futurism started venturing into architecture with the Manifesto dell'architettura futurista signed by Antonio Sant'Elia and written with Marinetti's input. Only a few new architectural elements were introduced: the oblique line, the importance of new materials to be used such as concrete, iron and glass to create a new synthesis between form, function and space. The oblique-errant line had to be developed in opposition to the straight and vertical line. The former was exemplified by the work of Piero Portaluppi in his contribution to a new visionary aesthetic in the Planetario Hoepli, ${ }^{47}$ which looked at the relationship between the urban space and individuality. 
More importantly, Futurist architecture is emblematic of a trajectory followed by many other contemporaneous artistic movements: shifting from the utopianism of the 1910s to the utilitarian and pragmatic view of the 1930s which, not unlike the unbalanced relationship between the national novel and translations we have already discussed, needed to account for the demands of a much wider public, since their audiences were no longer simply the affluent middle classes but the new urban populations flooding into old and new Italian cities from rural areas. ${ }^{48}$ Unlike Futurism, which hardly realized its ideas about architecture in practice, the Novecento movement never published manifestos but concerned itself with the act of building: the Novecentisti constructed extensively and continuously. Moreover, if Muzio was the leading exponent of the movement, it was, like the Gruppo 7, or later the BBPR, very much considered a collective enterprise based on a set of buildings and not on theoretical statements. The Novecentisti conceptualized the architectural work as a collective effort, turning it into a profession, and wholeheartedly rejecting the Futurist idea of the lone creative genius: they saw their practice as performing the social function of providing habitable public and private spaces (Etlin 1991, 329-67). Taken together, however, the Novecento movement and Futurism are characteristic of inter-war modernity: their awareness of their own theoretical practices and cultural traditions would be deployed to reshape the Italian/Mediterranean public sphere through structures able to assist the process of modernization. These concerns went hand in hand with the process of modernization which, for the novel, was closely connected with the publishing industry and the construction of a reading public, whereas for architecture it depended on State-commissioned works and support from the industrial sector, as was often discussed in Quadrante (Castronovo 1988, 12-16).

From 1931 through to 1935, the rationalist movement as a whole would create some of the most interesting architecture of the Ventennio, putting the main principles and spirit of this architectural renewal into practice. Because of their public role and contribution to the artistic and architectural debates, architects ${ }^{49}$ Giuseppe Terragni (1904-1943) and Giuseppe Pagano (1896-1945) and art critic Edoardo Persico (1900-1936) were to become the three most prominent figures of the period. That said, the rationalist movement did not begin as such, but it could be said to have 
started with the manifesto of the Gruppo 7. The first group of articles published in the little-known Rassegna italiana directed by Tommaso Sillani, from December 1926 to March 1927, proclaiming the new movement were signed by the Gruppo 7-Ubaldo Castagnoli (replaced by Adalberto Libera ${ }^{50}$ in 1927), Luigi Figini, Guido Frette, Sebastiano Larco, Gino Pollini, Carlo Enrico Rava and Giuseppe Terragni-all in their mid-twenties and students at the Milan Politecnico. As Droodan remarks, in the Rassegna articles the 'Gruppo 7 correctly identified most of the major issues which dominated the discussion of architecture in Italy for the next fifteen years: functionalism, rationalized typologies, contemporary aesthetics, respect for tradition, and the role of the individual architect' $(1988,52)$. Significantly, this 'new spirit' was fuelled by the likes of Cocteau, Picasso, Strawinsky and Le Corbusier, and it was the result of a new understanding of the idea of composition which had to be based on 'an harmonious resonance of simplicity and concision, which has to be clear and have a brisk rhythm' ('una risonanza armonica di semplicità, concisione, chiara e serrata'; Gruppo 7, 'Gli stranieri', op. cit. in Cennamo (1973: 52)).

Le Corbusier's Vers une architecture (1923) and Walter Gropius' Internationale Architektur (1925), together with the Peter Behrens, Heinrich Kosina, Erich Mendelshon, Arthur Korn, Hans and Wassili Luckhardt, Alexander and Leonid Vesnin or the Engelbert Mann popular houses in Vienna, were studied as seminal texts by the rationalists more generally since they provided the 'fundamental shapes' ('forme fondamentali') and the 'alphabet' ('alfabeto') for a new aesthetics (e.g. P. M. Bardi, BBPR, Gruppo 7, Pagano, Terragni). ${ }^{51}$ These architects presented themselves as the expression of a new spirit in architecture, which favoured Corbusian simplicity of forms, if not purism, which they termed 'the rhythm of construction' and a Gropiusesque return to a new objectivity. ${ }^{52}$ Above all, the Gruppo 7 and the rationalists believed in rationality as function, or in the perfect correspondence between the structure of the building and the purpose that it will serve.

Better housing and improved working environments for all social classes was the mission of social architecture, and especially so for Gruppo 7 , but to achieve their aims they needed to develop a new architectural language. ${ }^{53}$ Gruppo 7 's central call for a united effort involving aesthetic 


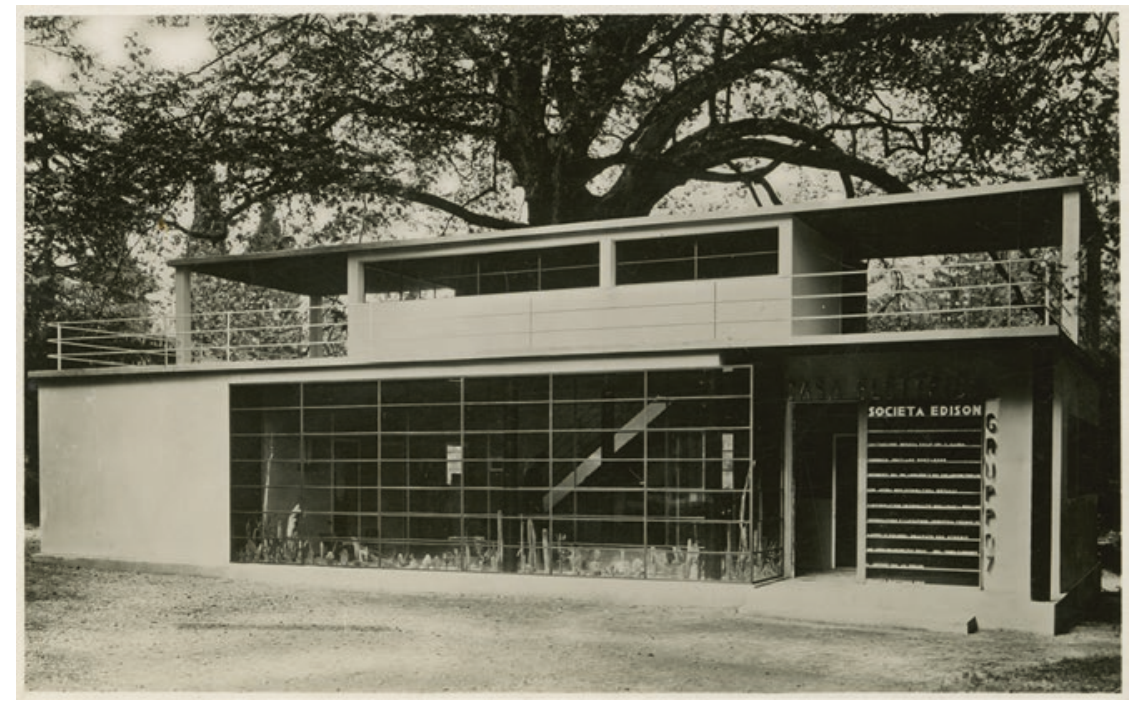

Fig. 4.1 Casa elettrica di Luigi Figini e Gino Pollini alla IV Esposizione Internazionale d'arte decorativa e industriale moderna di Monza (1929-1930). Veduta dell'esterno, 1 fotografia Mart, Archivio del '900, Fondo Luigi Figini e Gino Pollini, Fig.Pol. 3.1.1.6.1. 8

innovation and social modernization through the use of new materials and technology was realised in the Casa elettrica ${ }^{54}$ (a $16 \times 8$ metre rectangular structure with a large living area). While the plans were signed by the whole group, in reality it was the brainchild of the Rovereto-born Luigi Figini and Gino Pollini, and exhibited as the part of the IV Triennale, Monza, in 1930 (Nicoloso 2008, 19) (Fig. 4.1).

The Edison electric company sponsored the project, which showcased alternative materials and paid special attention to the infrastructure surrounding the new type of house. Of particular note is the 'cucina elettrica', the electric kitchen. It featured fourteen new types of appliances and numerous new-fangled pieces of equipment, all completely unknown to Italians, which were envisaged as a means of improving daily living conditions (albeit in a house for the middle classes) by rationalizing effort and the distribution of space. Milanese architect and planner Piero Bottoni designed the kitchen and drew inspiration from the works exhibited at the 1927 Deutscher Werkbund (Erna Mayer and J. J. Oud demonstration kitchen) and from 
Margarete Schütte-Lihotzky's Frankfurt Kitchen. As foreseen by Gropius and by Ludwig Mies van der Rohe's new architecture in Weimar as well as by Le Corbusier's machine for living, the Casa elettrica was an early example of the social transformation through technology that the regime itself was seeking in order to become a modern, modernizing nation-State (see Rifkind 2012, 91, for details of international influences and reception). Moreover, it was an example of the functional use of spaces and design in a united architectural project, featuring standardized designs (Figs. 4.2a and 4.2b).

In this respect, the description of Austrian-born architect Heinrich Kosina’s plans for a power station in Berlin (1925) is a fitting example:

Linked to the turbine shed, a bare, elemental space, devoid of shadow, is the switch house, its floor covered with a radial pattern of contrasting strips which create rhythmic horizontal rays alternating between light and dark. (Rassegna italiana, February 1927, in Cennamo 1973, 45) 55

Like la Casa elettrica, with its use of glass walls, geometric lighting and plan libre, an industrial building had to create harmony and functional integration between external and internal spaces. Linear, open-plan design and new technology had to facilitate the exchange with naturejust as the novel had to simplify syntax to create a closer understanding of reality and gain a 'naturalezza' without ornamentation (see Chap. 7). All this had to be realized by bringing together an attention to the formal properties of materials and the building's specific context with the absolute, rationalist and self-standing forms encapsulated in the new architectural design (Etlin 1991, 227-28 on the notion of the minimum house On the use of colour in the house, see Gregotti and Marzari 1997, 255-56). In all, by the end of the 1920s, Muzio, Figini and Pollini in their conception of the house achieved something similar to what had been theorized for the novel because of their constructive ethos and their attempt at negotiating the boundaries between modernity and tradition, through a process of geometrical rationalization and stylistic essentiality. This notion of narrative rationalization combined the principles of architectural theory, which regarded construction as the rationalization of forms engineered to fulfil a specific function, upheld, for example, in Giuseppe Terragni's Casa del fascio, or glass house (1936), with those 

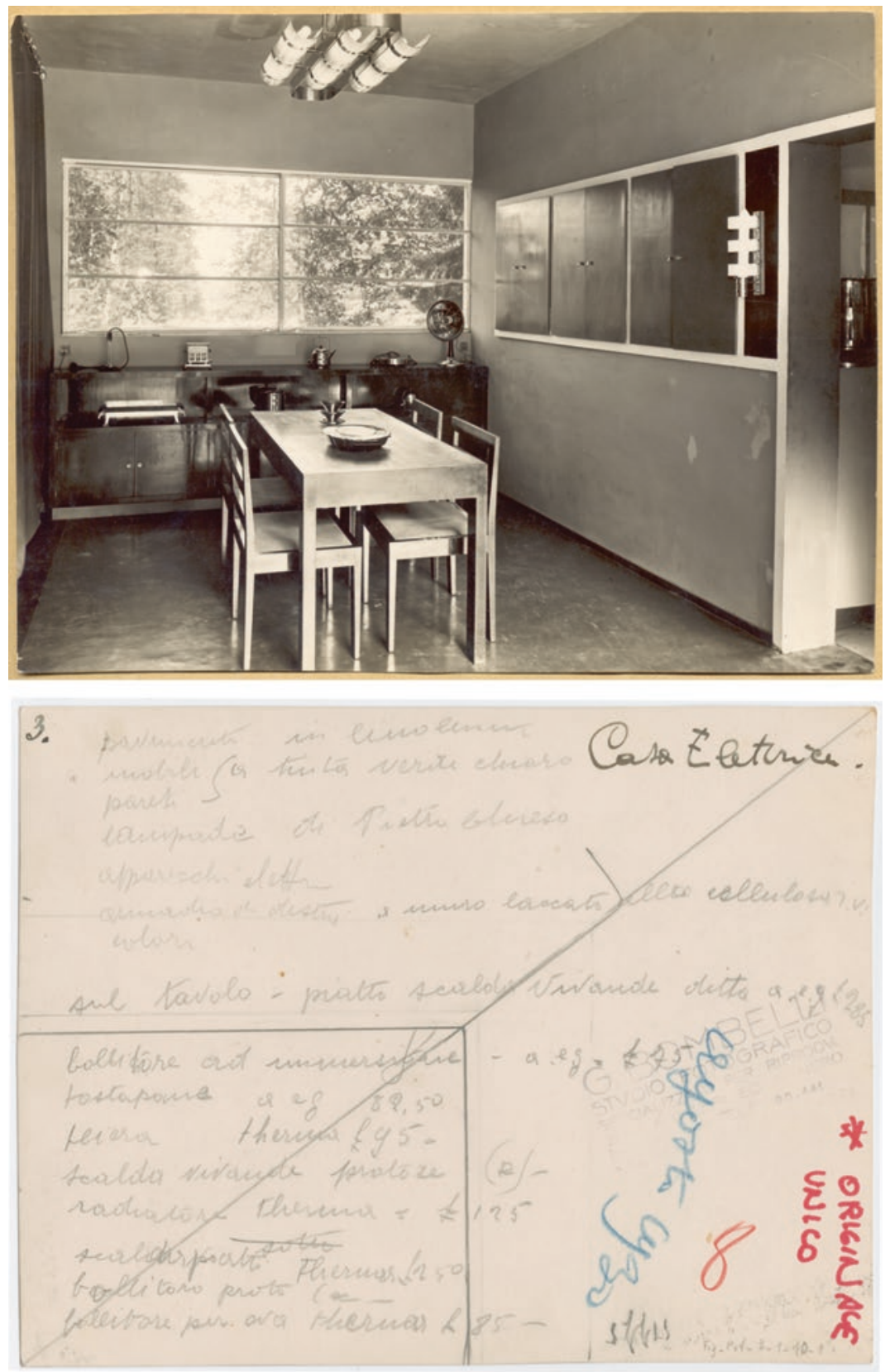

Fig 4.2 (a) La cucina della Casa elettrica di Luigi Figini e Gino Pollini alla IV Esposizione Internazionale d'arte decorativa e industriale moderna di Monza (1929-1930), 1 fotografia, ante/retro; (b) Mart, Archivio del '900, Fondo Luigi Figini e Gino Pollini, Fig.Pol.3.1.1.6.1.4 
governing the novel as a national project. Both concepts fused morality and a social mission with a new understanding of the relationship between the subjectivity of the character and the materiality of external reality, no longer understood as mutually excluding entities but as mutually functional to their interconnected existences (Irace 1982, 219-20). In narrative terms, if the prosa d'arte was the reflection of reality within the consciousness of the character, in realist writing, external reality was part of the shaping of subjective reality and vice versa. By way of conclusion on the rationalist house and its relationship with architecture, we can mention Gadda's critique of rationalist architecture. In his collection of novelle, I viaggi del Gulliver, cioè del Gaddus, we find a short piece entitled 'La casa'. The story's protagonist, the architect Basletta, is a rationalist and the main target of Gadda's critique of modern architecture. Rationalist architecture for the house is self-referential and forgets the needs of those who live in these newly built dwellings in order to pursue an aesthetic and economic mission. Gadda is in favour of old-fashioned houses with thick walls and richly furnished interiors, which just like his own expressionistic use of language do reflect the unresolvable struggles of humans en large (De Seta 1982, 214-15; see Schnapp 2012, 61-62, on the affinities between Portaluppi and his cousin Gadda).

Following the exhibition of rationalist architecture held in Rome in 1928 (March-April) at the Palazzo delle Esposizioni and staged amongst others by architects Adalberto Libera and Giovanni Minnucci, July 1930 witnessed the official birth of the Movimento Italiano per l'Architettura Razionale (MIAR), founded by Libera who served as its first secretary. Presenting the first exhibition, Libera and Minnucci stressed the importance of the relationship between modern architecture and the Italianand in particular the Roman-tradition, because they both shared a 'constructive power' and because of the parts of a building depend on the unity of its compositional patterns ('Presentazione dell'esposizione', in Patetta 1972, 155). ${ }^{56}$ By shifting the focus onto Rome's contribution to modern architecture through its classical tradition, the two architects tried to move the scene from Milan to Rome, and thus involve Piacentini. This extension of their geographical reach would bring the MIAR wider national appeal (Nicoloso 2008, 60). Hence, in 1931, at the second MIAR exhibition-larger, more confrontational and more controversial than the 
first-held at the Galleria di Roma, owner and curator Pietro Maria Bardi interceded in favour of rationalist architecture and pleaded directly to Mussolini to intervene in support of it. In his 'Rapporto sull'architettura (per Mussolini)', he stated succinctly but unequivocally that architecture had to be orchestrated by the regime and the arts too had to become a sphere under regime control. With his 'Rapporto', Bardi played on various fronts: against the Italian tradition of figurative architecture, against the Futurists and their attempt to hegemonize Italian vanguard design with Prampolini, Fillia and Depero, and with the goal of placing rationalist architecture firmly at the centre of State art as a true representation of contemporary reality. On the same occasion, Terragni expressed a view on modern architecture and State art, which was slightly different to Bardi's, as Ciucci notes: 'It is the collision between practical existence and the poetry of the architect: [...] it is necessary to ask the State to promote the conditions which will teach the public how to understand what the new architecture means' (2002 [1989], 117). ${ }^{57}$ The movement, which sought to bring together architects from all over the country as a united national front, would be dissolved shortly after, on September 51,931, when Gaetano Minnucci lost his university job at the Sapienza in Rome because of the strong reaction of the National Syndicate of Architects against Bardi's Tavola degli orrori ('Table of Horrors'). This tabletop collage mocked Piacentini's Torre Ina in Brescia and Italian traditionalist architecture more generally, especially the Italian pavilion for the Paris exposition of 1925 by Armando Brasini, whose work had been recommended to Mussolini by Margherita Sarfatti. As a consequence of Piacentini's second more violent response to the Tavola degli orrori, Minucci and Pollini decided to resign as secretaries of the Rome and Milan sections respectively, and no new leadership could be found ('Difesa dell'architettura italiana', Giornale d'Italia, 2 May 1931, XI: 3, in Pisani 1996, 168-73). Terragni had also declared that architecture needed to be promoted by the State in order to become the language used to visualize the myths created by the Fascist regime and embody them in concrete architectural terms - taking a position not dissimilar to that developed by Bontempelli in his theory of the novel and by Bardi himself (see Chap. 5). According to Nicoloso too, the problem faced by the new architecture was one of representation. In Pagano's idea of rationalist architecture, the lack of a 
figurative dimension prevented it from becoming State art, which primarily needed to be able to create the mythological repertoire of the revolution (Nicoloso 2008, 63).

Yet, while short-lived and soon under attack, the MIAR still represented the first attempt at creating a national organization of rationalist architects, with branches across the country (Turin, Rome and Milan) and various subsections, and also the first concerted attempt at promoting an aesthetic paradigm fusing realism (paying attention to context and tradition), morality and construction. As translations did for the novel, architecture too helped Italian culture to remain on the European map. For the most significant architectural manifestos of the twentieth century hailed, respectively, from Berlin, with a unity of technique which does not necessarily mean renouncing individuality while still remaining rigorous (Bauhaus, 1919); from Moscow, with the rejection of decorative elements (Naum Gabo and Antoine Pevsner, Constructivism, 1920); from France, with the ordering of forms and contours (Le Corbusier, 1923); and collectivist architecture in the De Stijl Manifesto V: $-\square+=$ R4 (Paris, 1922), and finally to the rejection of all aesthetic speculation, of all doctrines, and of formalism (Ludwig Mies van der Roher, 1923). By the end of the 1920s, theoretical declarations on architecture became more frequent, from Bernhard Hoetger, who defined it as the most popular artistic form (World 1928), to the emphasis placed on its public dimension by the CIAM (Congrès internationaux d'architecture moderne) at the Chateau de la Sarraz, Switzerland, in 1928, to the declaration of the absolute authority of objectivity by El Lissitzky upon his return to Moscow from Paris in 1929. In 1932, the American architect R. Buckminster Fuller consecrated architecture as the universal art, founded upon the harmonious equilibrium between space and time. The thread running through these European experiments had been the strongly felt need to reconceptualize the relationship between aesthetics and technique in order to create new spaces and forms, which were no longer meant for the individual but rather for the individual as part of a collective project, and which could thus assume universal value.

As with the novel, the crux of the matter was to find a suitable position between foreign influences and the Italian tradition, between captivating plots and morality. This is where the Italian architectural field could meet 
with the international scene, as Piacentini himself admitted in 'Nostro Programma' (January 1931) published in the first issue of Architettura, the official journal of the national Syndicate of Architects. As we have seen in the case of translations versus the national novel, Italian architects, Piacentini wrote, must enter into dialogue with the international avant-gardes to strengthen the national tradition and eventually triumph over the other artistic movements, notably Sarafatti's Novecento (1-2). In order to preserve his influence, however, Piacentini was prepared to split the field somewhat: modern, cosmopolitan architecture was the architecture of the everyday, while monumental, ${ }^{58}$ classical architecture was the style for public art, open spaces and State-funded projects. In January 1931, before the Tavola degli orrori, Piacentini had already taken an adversarial position against modern architecture spurred by Dedalo, a conservative journal directed by leading art critic Ugo Ojetti, who never approved of rationalist architecture ('Dove è irragionevole l'architettura razionale.' no. 3: 527-40, in Pisani 1996: 161-67). Piacentini’s violent reaction in the press — with the labelling of rationalists as Bolsheviks and the demolition of the international scene (Gropius, Le Corbusier, Oud) caused significant damage to the movement, then still in its infancy. Crucially, he denied the connection between modern architecture and national architecture, thereby dismantling the rationalists' ambition to gain a hegemonic position within the field of State art.

Despite Piacentini's attacks, from 1932 onwards, on Adalberto Libera and Mario de Renzi's rationalist-modernist façade ${ }^{59}$ for the Mostra del Decennale, modern architecture, albeit not rationalist architecture per se, became more directly associated with State art, a State that in a benjaminesque-gropiusesque fashion sought to use technology, in particular media technology, to reproduce itself, its history, and to parade its efforts in public. ${ }^{60}$ At the Mostra della Rivoluzione, neither classicism nor traditionalism was on display, while Terragni in the Sala O, ${ }^{61}$ at the prestigious Sala del 1922, turned his gaze back to the pioneering work of Sant'Elia and the Constructivist movement, both understood as revolutionary directions to follow in the design of public spaces (revolution itself being the process whereby the boundaries between the public and the personal have been eroded). ${ }^{62}$ On 4 August 1932, praising Mussolini's collective revolution, Bardi wrote how this modern political system had 
changed the lives of Italian citizens down to their daily habits and spaces of activity: hence, architecture had to be about clear compositional language and the sharing of collective spaces. ${ }^{63}$ As was the case for the novel, commented the avant-gardist and true 'Bolshevik', Immaginist and architect $^{64}$ Vinicio Paladini, rationalist architecture ran the risk of becoming bourgeois if it were to follow in Piacentini's footsteps and welcome traditional monumentalism, thereby rejecting innovation. ${ }^{65}$ Journalist, writer and squadrista Alessandro Pavolini instead declared in the Bargello, a bastion of Fascist ideas which he had founded in Florence, that the rationalist movement could help Italy to regain moral and 'aesthetic' ascendancy over other nations (1932, 'Risposta a Ojetti sull'architettura.' 4, no. 18 (1 May): 3). Simultaneously, Piacentini, again in Architettura, sought to annihilate rationalist architecture by describing it as a formal problem totally detached from social and moral questions, and from the reality of citizens' lives. In sum, 1932 saw the first centrifugal tendencies within the architectural movement with the return on the scene of Marinetti and Futurist architecture, but also the beginning of the realization of some of the main State-commissioned projects, which would define the Ventennio in architectural terms.

\section{The Languages of Architecture}

Architecture was public art par excellence, an art which inhabited public spaces and tried to function as a space where citizens could be more or less forcefully integrated into the State (Nicoloso 2008, 55). ${ }^{66}$ From 1927 to 1932, the regime was moving forward with its campaign for the 'andata al popolo' and it needed visible evidence of its efforts: architecture can serve this purpose and it is one of the intriguing features of the modern movement in Italy that "it minimized "functionalist" and "machine-age" polemics, playing up instead an abstract aestheticism' (Curtis 1982, 218).

From 16 February 1932 to 31 October 1935, another united front was formed in both aesthetic and political terms: the Città Universitaria ${ }^{67}$ in Rome's, La Sapienza university, was the result of a compromise between rationalists and Piacentini, 'a first step towards a more organic and incisive presence for architecture within the totalitarian State' 
(Nicoloso 2008, 81). ${ }^{68}$ Crucially, Piacentini was now involved in three important projects: the Piazza della Vittoria in Brescia, the new university complex at La Sapienza, and from 1933 onwards, the first competition for Florence's train station. ${ }^{69}$ In terms of the new architectural language, the Città Universitaria, encapsulates the unity that Bardi and Bontempelli were calling for in Quadrante, by tracing 'a symmetrical plan, which makes use of the classical "model" of the basilica' (Nicoloso 2008, 194). Stylistic unity was achieved through the rationalization of forms according to a shared paradigm, in this case the use of standardized window and frame designs, and the use of similar materials such as travertine marble, glazed brick and yellow and red plaster; but the function of these designs was public and collective and not individual yet socially functional as in the Ca' Brutta, or in the Casa elettrica. If stylistic unity meant a willingness to renounce individuality and to act in a socially responsible way, it needed to be deployed carefully in order to favour collectivity.

At the dissolution of the MIAR, Marinetti had leapt at this opportunity to claim that Futurist architecture was not only the one true State art, but the only real national art. ${ }^{70}$ Particularly from the Fascist Revolution exhibition onwards, Futurism came to the fore with C. A. Poggi's Manifesto dell'architettura in 1933, followed in 1934 by the Manifesto futurista dell'architettura aerea by Angiolo Mazzoni, Filippo T. Marinetti, Mino Somezi, and publications such as La nuova architettura in 1931, and La Città futurista (1929) and La Città nuova (1932-1934) by Fillì in Turin. ${ }^{71}$ Futurist publications such as Futurismo (1932-1933) directed by Mino Somezi, Nuovo futurismo by Antonio Marasco (1934) and Stile futurista (1934-1935) by Fillìa and Prampolini devoted substantial attention to architecture in the context of State art and to the synergies between artistic expressions, namely aero painting and aero sculpture. Of particular interests to the Futurists is how architecture could be functional to the development of the urban fabric, if supported by the State through public competitions (Gino Levi-Montalcini, 1932, 'Architettura Arte di Stato' 1, 'Futurismo' (11 December): 6). Meanwhile, under the banner of Futurist architecture, Angiolo Mazzoni engaged in the construction of some 20 public buildings, from Sicily to TrentinoAlto Adige, including train stations and post offices, while the rationalist 
movement reached the zenith of its exposure. All these experiments shared the same aesthetic premise: the recalibration of the relationship between the subjective and the objective and the rationalization of lines to construct a public space for the masses based on principles drawn from international architecture and the classical tradition. However, the Futurists insisted on the importance of the lyrical element in the act of building embodied in mural mosaics such as those in the post offices of La Spezia ${ }^{72}$ by Fillìa and Prampolini (1935) and in Palermo a sequence of five mural frescos by Benedetta Cappa and two large paintings by Tato (1934) (Ratti 2003, 292; Lima 2003, 251-54). ${ }^{73}$

In the early 1930s, following in the footsteps of Sant'Elia, Futurism returned to the architectural scene with a more pragmatic and constructivist ambition (the high-rise Torre Littoria in Turin) and Mazzoni was the person to bring all these projects to fruition. The Palazzo delle poste ${ }^{74}$ in Pula (1930-1935) coalesced rationalism, the 'edificio-tipo' and Futurist architecture together with its cylindrical vestibule and circular staircase. The cylinder-like volume at the entrance and the ribbon windows were particularly significant elements of Futurist public art insofar as they fused experimentation with volumes, transparency and openness of public space with solidly assembled supporting structures (Fig. 4.3).

In 1933, for the first time, the V Triennale in the new Palazzo dell' Arte $^{75}$ in Milan was dedicated to architecture and not to the decorative

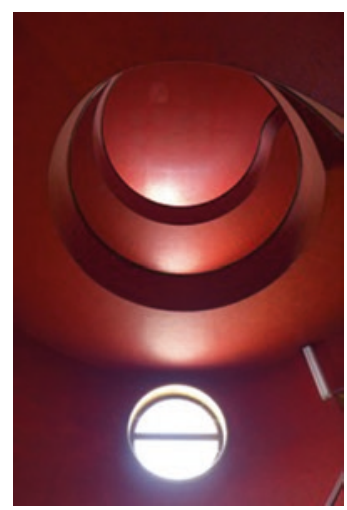

Fig. 4.3 Angiolo Mazzoni, Palazzo delle Poste di Pola (Croatia), courtesy of Katrin Albrecht 
arts as had previously been the case and its name changed from Esposizione internazionale delle arti decorative to the Esposizione internazionale d'arte decorative e industriali moderna. The Casa del sabato per gli sposi by the BBPR group and Piero Portaluppi, Umberto Sabbioni and Luigi Santarella, and the Villa-studio per un artista' by Figini and Pollini with Guido Frette were examples of this call for an architecture for the everyday which was functional, and thus modern, and tailored to the needs of new social actors and sectors, as Sironi, in charge of the overall design of the Triennale, had declared in his call for collective art in the Manifesto della pittura murale, and now presented in terms of the necessity for collaboration across artistic fields (Sironi, 'Architettura ed arte.' 8 January 1933, Popolo d'Italia, in Scritti, 138). ${ }^{76}$ In an anonymous article in Casabella, we read that the Casa per gli sposi is an example of totality in modern architecture; Marinetti (eager to promote Futurist architecture) praised it as modern, and Renato Camus in Edilizia moderna called it an elegant example of 'construction'. ${ }^{77}$ The Villa studio also attracted significant attention, helped by works by visual artists: Lucio Fontana's polychrome statue of a bather reclining on the edge of the swimming pool, Angelo Del Bon's chiaroscuro fresco and Fausto Melotti's equestrian figure decorated the internal rooms, defining focal points and creating volumetric symmetries. The Villa studio showcased the intersections between the arts advocated both by Quadrante and the regime. Abstract artist, author of the influential KN (1935), Carlo Belli could not but review it positively in the second issue of Quadrante (Rifkind 2012, 70-71). Despite its highly abstract functionalist design, the Villa is an expression of Figini and Pollini's desire to combine classicism-in its pure abstract form as praised by Belli-with an increased focus on mediterraneità and the spirituality of the environment, a forerunner of the perfect consonance with the local landscape achieved by Libera with the Villa Malaparte in Capri (1937). Reality, then, had once again to be filtered through rationalized forms and in this way made 'functional' for everyday life according to the 'spirito latino' and create a sense of metaphysical elation that was not too far removed from theorizations of the novel in this period (Trivellin 1996, 104-16, and Sironi, 'Architettura ed arte.' cit., in Scritti, 137 on forms of artistic cross-fertilization). ${ }^{78}$ The courtyards (cortile a impluvio and cortile del pruno) com- 
bined romanità pompeiana with Le Corbusier's purist house design, especially in the floor layout, which mixed open gardens and closed internal spaces in a rationalized labyrinthine whole (Rifkind 2012, 94). The development of the design of the villa is indicative of a broader trajectory: moving from the fragmented, encyclopaedic design of Muzio's Ca' Brutta to a more cogent and coherent attempt at shaping a functional, stylistically minimal environment for the specific tasks and moments of individual life. The rationalist villa is not a collective building but a space built according to a rationalized geometry and stylized idea of modern living, a practical and conceptual turn which runs parallel to what we have seen in the theory and practice of the novel in the previous chapter.

Within the rationalist group, from 1932 to 1934, the debates took two main paths. On the one hand, there was Pagano's idea of architecture as an assembly of pure forms, embodying high morals but lacking any representational aspirations, which could mould the style and image of a modern State and a mass dictatorship; and on the other, there was Terragni's vision of architecture as principally a social construct, which could help the individual to flourish within the formal structures of the State. Terragni was not concerned with architecture as morality but rather as a social experiment, and with the 'everyday which becomes a small piece in the construction of this "new solid world" of which Bontempelli spoke' (Ciucci 2002 [1989], 148). According to Pagano, architecture was a matter of linearity, of rationalization of forms, expressed in a lucid and morally rigorous language (Ciucci 2002 [1989], 146). ${ }^{79}$ He contested Terragni and Quadrante's claim that architects can guide and control reality through their rational architectural projects. According to Pagano, modern architecture needed to distinguish itself from the past by imposing an anti-rhetorical statement about aesthetics. Modernity is anonymity; it is the voice of the new crowds, meeting in public spaces which carry the myth-making power of the regime. And this was the new language which architecture needed to develop, just as the novel, and especially Bompiani's collective novel, required an anti-rhetorical form of prose writing in order to voice collectivity over individuality (Ciucci 2002 [1989], 144-145, see Chap. 7). 
Other milestones in these architectural wars were the 1933-1934 competitions for Florence's train station, ${ }^{80}$ Santa Maria Novella, won by the Gruppo Toscano led by Michelucci (1932-1936) and for the Palazzo del Littorio (today known as the Farnesina, the Ministry of Foreign Affairs). We will discuss the project for the Florence train station in greater detail in Chap. 7. As far as the 1934 competition for the Palazzo del Littorio in Rome was concerned, 'it formed [...] the crucial point upon which to exert the leverage necessary to bolster the idea that "modern" architecture was the only possible kind of architecture for the "modern” Fascist State' (Ciucci 2002 [1989], 141; Nicoloso 2008, 63). ${ }^{81}$ In 1934, Piacentini was amongst the judges and Pagano did not submit a project; he was himself indirectly acting an external assessor from Casabella. ${ }^{82}$ In the Renaissance tradition, the Palazzo, the headquarters of the Fascist Party, needed to impose itself on the landscape of the capital city, and project authority through a monumentalism achieved by compositional unity. It is interesting to note that two projects, submitted by the Montuori-Piccinato group and the Banfi group respectively, were deemed (too) 'modern' and rejected by the panel for this very reason. The former did, however, receive Pagano's support because it was 'modest, anti-rhetorical and had a moral message', while the latter was rightly seen as being in touch with European influences (Giuseppe Pagano, 1934, 'Il concorso per il Palazzo del Littorio. ${ }^{83}$ Casabella 82, no. 8 (October), in De Seta 2008, 20-29). Pagano was of course critical of monumentalism when used as a way of glorifying the regime, instead of being conceived of and used as a means both of supporting the lower classes and of facilitating the development of Fascist civilization. ${ }^{84}$

Terragni also entered the competition with two projects, 'soluzione A' and 'soluzione B'. Piacentini complimented him for having attempted to combine monumentalism with the pressures of social reality (Ciucci 2002 [1989], 147; Nicoloso 2008, 75-77). However, even though Terragni's works had so far been designed to accommodate the masses, ${ }^{85}$ according to the panel, on this occasion, his two projects, especially the second one, were worryingly influenced by abstract, rationalist, foreign models, and were too elitist in conception. ${ }^{86}$ The gruppo Foschini (Enrico del Debbio, Arnaldo Foschini, Vittorio Morpurgo) won the competition in October 1937. Theirs was a traditional project, but unlike Terragni's 
monovolumetric 'soluzione B', it was certainly a project which could speak to the masses by adopting a figurative, iconic and accessible language that from 1934 onwards the regime would privilege in public art (e.g. the stile littorio). Morality in art was now expressed through a traditional, but reconstructed syntax, which looked less towards the Mediterranean and more to the classical tradition, but which needed to embrace an accessible, figurative language. Although the competition provoked disagreement, it was a milestone insofar as it demonstrated the variety of languages spoken by Italian architects.

From 1935 onwards, Piacentini officially became the leading architect in Italy and he proceeded to sideline rationalist architecture, since its experimental drive was far too removed from the social problems, which the regime, with the decline of consensus, had to tackle. By 1936, as already mentioned, the split between the Milanese Pagano school, more attentive both to the needs of the citizens as social and personal entities and to formal experimentation, and the Rome-based school led by Piacentini, which was moving rapidly from classicism to monumentalism, became starker as the latter gradually overtook the former. The other clear emerging trend was the tension between international aspirations and about the claimed moral ascendancy of the national tradition. After 1936, with Italy's progressive isolation from the international scene after the invasion of Ethiopia, we see a change in architectural language, with a shift towards a more educational and propagandistic tone. Piacentini expressed a new understanding of the role of public architecture ${ }^{87}$ : the restoration of Brescia's town centre, the piazza della Vittoria, showed how monumentalism could refashion classical architecture not, as before, in international terms but now as an attempt to consolidate an imperialist tradition, which resorted to clear symbols of domination and grandeur to suit a new political and institutional configuration (Cresti 2015, 17; Nicoloso 2008, 204-09).

Following the triumph of Piacentini's monumentalism over rationalist architecture, one project notable for of its use of classicism is the Sala della Vittoria ${ }^{88}$ for the VI Triennale in 1936, designed by Edoardo Persico (1900-1936), featuring white-on-white monochrome of the Vittoria and the Cavalli rampanti by Lucio Fontana, Giuseppe Palanti 
and Marcello Nizzoli (Salvagnini 2000, 65-67). The Salone d'Onore is a fine expression of the guiding principles of the architectural movements we have described so far and of a brand of monumentalism which rejected bombastic rhetorical statements in favour of linearity, unity, construction and an anti-rhetorical style, creating an almost magical atmosphere. Persico on the one hand, and Fontana, Palanti and Nizzoli on the other, chose classical forms for the Salone d'Onore because they all believed that classical composition should not be bound to a specific sociopolitical configuration; rather, the universalism of the classical tradition would confer an absolute and ethical value upon rationalized and chromatically coherent forms emphasized by the parallel light beams focusing the visual perspective on the statue of Victory. Classicism thus functioned as the chief symbol of a culture, Fascist in this case, which aspired to a perfect equilibrium between art and construction with a balanced-and universal-(universal) stylistic approach: in other words, to purity and unity (Ciucci 2002 [1989], 150-51; Giò Ponti, 1936, 'La sala della Vittoria.' Domus 15, n. 103 (July): 3). Although the exhibition inside the Palazzo dell'Arte was about the house and its furnishings, in the pavilion in the park, Pagano and Daniel's exhibition celebrated the same quality which interested Pagano: 'the aesthetic and moral value of functionality [...]. The elements of architecture must be virtually anonymous, collective, perfectible' (Ciucci 2002 [1989], 162; Danesi and Patetta 1988, 83). The 1936 Triennale, like Bontemplelli's Scacchiera davanti allo specchio, expressed architecture's mythical, ethereal side and the need for morality to remain quietly anchored in everyday reality.

In 1937-1938 the regime's closing era began, culminating in the planning for the never-completed complex for the E42 Exhibition. ${ }^{89}$ This was to be the most monumental of all the projects orchestrated by the regime, with a distinctly pedagogical and propagandistic intention and led on one side by Piacentini and on the other by Pagano. All important architects (Del Debbio, Libera, Michelucci, Muzio, Terragni, the BBPR) were involved to some extent in the project, since architecture now had to work for the regime in constructing myths, based here on the Roman mythology, with very little scope for deviation. The E42 was the expression of the power of images to involve 
Italians in the life of the regime, and also of the close collaboration between Piacentini and Mussolini in forging a new architectural, monumental and figurative language, which could express the link between aesthetics and power (Gentile 2009, 201; Nicoloso 2008, 196). ${ }^{90}$ In the last major endeavour supported by the regime at the end of its life, Mussolini took the side of the classicist-monumentalists (e.g. the Palazzo della civiltà, the Palazzo dei Congressi and the Palazzo dell'Ina). Pagano was clearly uncomfortable with the project for obvious reasons, but it was Giuseppe Bottai who most forcefully condemned it, reflecting the failure of Mussolini's late artistic policies in the context of WWII. The E42 did not reflect the artistic policies he had been developing since the mid-1920s when he had started promoting artistic eclecticism over a unique style or State art. By 1942, as with his earlier defence of Primato's cultural agenda of 'azione-cultura', Bottai was fully aware of the need to 'save' what could still be rescued. His dismissal of Mussolini's monumentalism was yet another expression of his effort to rescue Fascism from Mussolinism.

The value attributed to architecture throughout the Ventennio, however, rested on its social impact. The debate on the novel emphasized similar aspects: social significance, collective ethos, construction over fragmentation of narrative structure. To a certain extent, both were social experiments insofar as they appealed to the idea of radically changing the daily lives of Italians and in so doing become State art, erecting an overarching aesthetic and political order. Both projects called aesthetically for a return to simplicity of execution to favour the sharing of collective spaces. In both cases, a lucid, clear and direct relationship with the materiality of reality was sought-whether in writing or in public buildings, such as in the corporative cities. The spirit had to be anti-bourgeois and in contact with the real. This was to translate politically as a new rationalized dimension of the relationship between the citizen and the State. State art, up until the mid-thirties, thus favoured a pared-down aesthetic construction, which had to eliminate any excess in order to rationalize the experience of daily life for Italians, particularly in collective spaces. By the end of the regime, however, it had become a rhetorical device without resonance. 


\section{Notes}

1. http://dialecticsofmodernity.manchester.ac.uk/tag/functionalist-architecture; http://dialecticsofmodernity.manchester.ac.uk/tag/fascistarchitecture; http://dialecticsofmodernity.manchester.ac.uk/tag/ futurist-architecture; http://dialecticsofmodernity.manchester.ac.uk/ tag/monumentalism

2. The critical literature on architecture during the Fascist regime is vast and offers a thorough analysis of its historical development; for the purposes of this chapter, it is worth mentioning the works of Ciucci (2002 [1989]), Cresti (1986), Danesi and Patetta (1988), Doordan (1988), Etlin (1991), Nicoloso (2008), which present the most comprehensive and sustained analysis of the architectural field during the Ventennio.

3. For a detailed discussion of Wagner's use of the world and its political reverberations, see Pederson (2016, 43-46).

4. For an exploration of these intersections, with a specific view on architecture and the other arts, see Patetta, in Mozzoni and Santini (2009, 3).

5. http://dialecticsofmodernity.manchester.ac.uk/essay/499

6. http://dialecticsofmodernity.manchester.ac.uk/artefact/33; http://dialecticsofmodernity.manchester.ac.uk/artefact/34; http://dialecticsofmodernity.manchester.ac.uk/artefact/35; http://dialecticsofmodernity. manchester.ac.uk/essay/395; http://dialecticsofmodernity.manchester. ac.uk/essay/397; http://dialecticsofmodernity.manchester.ac.uk/ essay/394; http://dialecticsofmodernity.manchester.ac.uk/essay/396

7. See Roberts $(2011,2)$ and, on Prampolini's idea of totalising architecture, Ori (2014, 26-27). On Mazzoni's Futurist architecture, see Mangione (2009, 9-45). For a detailed technical account of Mazzoni's projects for Italian train stations, see Neudecker (2007, 59-192).

8. http://dialecticsofmodernity.manchester.ac.uk/essay/436; http://dialecticsofmodernity.manchester.ac.uk/artefact/112

9. http://dialecticsofmodernity.manchester.ac.uk/artefact/241; http:// dialecticsofmodernity.manchester.ac.uk/artefact/242; http://dialecticsofmodernity.manchester.ac.uk/essay/511

10. For an analysis of cultural flows between Germany and Italy in the late 1920s and early 1930s on the subject of the total work of art and total theatre, especially the BL18, see Schnapp (2012, 99-114) and Rifkind $(2012,13)$. 
11. http://dialecticsofmodernity.manchester.ac.uk/artefact/19; http://dialecticsofmodernity.manchester.ac.uk/essay/414; http://dialecticsofmodernity.manchester.ac.uk/essay/405

12. http://dialecticsofmodernity.manchester.ac.uk/artefact/130; http:// dialecticsofmodernity.manchester.ac.uk/artefact/143; http://dialecticsofmodernity.manchester.ac.uk/essay/419

13. http://dialecticsofmodernity.manchester.ac.uk/artefact/240; http:// dialecticsofmodernity.manchester.ac.uk/artefact/241; http://dialecticsofmodernity.manchester.ac.uk/artefact/242; http://dialecticsofmodernity.manchester.ac.uk/artefact/244; http://dialecticsofmodernity. manchester.ac.uk/artefact/102; http://dialecticsofmodernity.manchester.ac.uk/artefact/103; http://dialecticsofmodernity.manchester.ac.uk/ essay/451; http://dialecticsofmodernity.manchester.ac.uk/essay/482; http://dialecticsofmodernity.manchester.ac.uk/essay/512; http://dialecticsofmodernity.manchester.ac.uk/essay/511

14. http://dialecticsofmodernity.manchester.ac.uk/artefact/225; http:// dialecticsofmodernity.manchester.ac.uk/artefact/226; http://dialecticsofmodernity.manchester.ac.uk/essay/517; http://dialecticsofmodernity.manchester.ac.uk/essay/517

15. http://dialecticsofmodernity.manchester.ac.uk/artefact/129; http://dialecticsofmodernity.manchester.ac.uk/artefact/136; http://dialecticsofmodernity.manchester.ac.uk/artefact/143; http://dialecticsofmodernity. manchester.ac.uk/essay/420; http://dialecticsofmodernity.manchester. ac.uk/essay/463; http://dialecticsofmodernity.manchester.ac.uk/ essay/433; http://dialecticsofmodernity.manchester.ac.uk/essay/419

16. http://dialecticsofmodernity.manchester.ac.uk/essay/409

17. http://dialecticsofmodernity.manchester.ac.uk/artefact/137; http:// dialecticsofmodernity.manchester.ac.uk/essay/427

18. http://dialecticsofmodernity.manchester.ac.uk/essay/456

19. http://dialecticsofmodernity.manchester.ac.uk/essay/464

20. http://dialecticsofmodernity.manchester.ac.uk/essay/437

21. http://dialecticsofmodernity.manchester.ac.uk/artefact/105; http:// dialecticsofmodernity.manchester.ac.uk/essay/454; http://dialecticsofmodernity.manchester.ac.uk/essay/495

22. http://dialecticsofmodernity.manchester.ac.uk/artefact/116; http:// dialecticsofmodernity.manchester.ac.uk/essay/436; http://dialecticsofmodernity.manchester.ac.uk/essay/407 
23. Notable examples are Prampolini's cosmic experiments, especially in aero painting (Lista 2013, 211-26).

24. http://dialecticsofmodernity.manchester.ac.uk/tag/totalitarian-art

25. 'A mio giudizio la massima di tutte le arti,_- disse Mussolini,_- è l'architettura, perchè comprende tutto'. 1932. 'Colloqui con Mussolini sull'arte.' L'Italia letteraria 4, no. 27 (3 July): 1. See also the article by Bernardo Giovenale, 1933, 'Avvenire delle corporazioni.' Quadrante 1, no. 4 (August): 2-7, where he reinforced the point regarding Fascist doctrine being about the collective sense of life.

26. http://dialecticsofmodernity.manchester.ac.uk/essay/414

27. http://dialecticsofmodernity.manchester.ac.uk/essay/522

28. http://dialecticsofmodernity.manchester.ac.uk/artefact/41; http://dialecticsofmodernity.manchester.ac.uk/essay/497; http://dialecticsofmodernity.manchester.ac.uk/essay/494

29. http://dialecticsofmodernity.manchester.ac.uk/essay/481

30. http://dialecticsofmodernity.manchester.ac.uk/essay/518

31. http://dialecticsofmodernity.manchester.ac.uk/essay/393

32. http://dialecticsofmodernity.manchester.ac.uk/essay/418

33. These buildings have been extensively discussed in the context of the role of architecture in State art; see, for example, Storchi $(2007,237-$ 44 ) and Schumacher (1991, 140-70). See also Bontempelli's praise of Terragni's use of glass, in L'avventura novecentista, September 1936, 336.

34. For a detailed discussion of the technical specifications of the Casa del fascio, see Federica Dal Falco, 'Caratteri costruttivi' (2002, 13-33).

35. http://dialecticsofmodernity.manchester.ac.uk/artefact/25; http://dialecticsofmodernity.manchester.ac.uk/essay/405; http://dialecticsofmodernity.manchester.ac.uk/essay/480

36. Two examples are particularly telling regarding this transition. The first was the violent polemic, published in La Tribuna between 2 and 26 February 1933, between Piacentini and Ugo Ojetti over the use of arches and columns, with the former accusing the latter of not being able to accept the changes required by the new society (see Piacentini 'Gli archi e le colonne e l'italianità d'oggi' and 'Archi e colonne' in Pisani 1996, 182-190). The second was Piacentini's article on the competition to design the Palazzo del Littorio. He accepts new architecture as long as it is placed in the service of the regime (1934, 'Il concorso nazionale per il progetto del Palazzo del Littorio e della Mostra della Rivoluzione 
Fascista in via dell'Impero.' Architettura XIII: 3, cited in Pisani 1996, 191-92). Doordan sees 1936 as a watershed moment for architecture (Doordan 1988, 143).

37. http://dialecticsofmodernity.manchester.ac.uk/artefact/26; http://dialecticsofmodernity.manchester.ac.uk/essay/401; http://dialecticsofmodernity.manchester.ac.uk/essay/470

38. http://dialecticsofmodernity.manchester.ac.uk/essay/432

39. For the history of the Ca' Brutta, see Etlin (1991, 166, 180-81) and Irace $(1994,5)$. Equally important 'Novecento style' houses were Giuseppe de Finetti's Casa della Meridiana (1925, Milan) and Giuseppe Pagano's office-building Palazzo Gualino (Turin, 1928-1930) with their use of hyper-rationalised linear patterns and volumes combining classical linear rigour with modern functionality.

40. http://dialecticsofmodernity.manchester.ac.uk/essay/505; http://dialecticsofmodernity.manchester.ac.uk/essay/506; http://dialecticsofmodernity.manchester.ac.uk/essay/486

41. http://dialecticsofmodernity.manchester.ac.uk/essay/505

42. For a discussion of the key ideas expressed in the Manifesto, which originated from the soirées at Sarfatti's Milanese salon, and especially for the change in meaning of the word 'sintesi' (synthesis) as theorised by the Futurists first and then revised by Sarfatti and the Novecento movement, see Pontiggia (2003, 159-75). The Manifesto was written in opposition to the Valori plastici movement and De Chirico, Savinio and Carrà to call for a work of art which was synthetic, composition, construction and not fragmentation (161).

43. The artistic movement would be publicly endorsed three years later at Lino Pesaro's elegant gallery by Mussolini on 26 March 1923. Novecento stood for a return to tradition and classical tradition, combined with the need to express modern values. On this famous occasion, Mussolini dismissed the idea of State art and admitted that the artistic sphere was an integral part of the sphere of the individual, 'Alla mostra del Novecento. Parole di Mussolini sull'arte e sul Governo.' Il Popolo d'Italia, 27 March 1923. A similar conceptualization, only expressed in stronger terms, would be reiterated on 5 October 1926 at the Accademia delle Belle Arti di Pesaro, with the official consecration of Novecento as a movement. Mussolini now explicitly called for a new art, a Fascist art attuned to the present historical moment, but not directed by the regime (see Chap. 2). 
44. For a comprehensive cultural and technical analysis of the Novecento and rationalist Milanese houses of the 1930s, see the recent volume edited by Isastia and Pierini (2017).

45. For a reading of the $\mathrm{Ca}$ Brutta aesthetic premises in relation to the Valori plastici movement, see Isastia (Isastia and Pierini 2017, 468-69).

46. On Loos' influence on the Novecento movement, see Droodan's analysis of the Pizzigoni House, 1925-27, $(1988,38)$.

47. http://dialecticsofmodernity.manchester.ac.uk/essay/498

48. 1930, Mostra di Onoranze all'architetto futurista Antonio Sant'Elia, Como.

49. http://dialecticsofmodernity.manchester.ac.uk/artefact/20; http://dialecticsofmodernity.manchester.ac.uk/artefact/37; http://dialecticsofmodernity.manchester.ac.uk/essay/417; http://dialecticsofmodernity. manchester.ac.uk/essay/416; http://dialecticsofmodernity.manchester. ac.uk/essay/415

50. http://dialecticsofmodernity.manchester.ac.uk/artefact/30; http://dialecticsofmodernity.manchester.ac.uk/essay/492; http://dialecticsofmodernity.manchester.ac.uk/essay/491

51. Gruppo 7, 'Gli stranieri', in Cennamo (1973, 51). In 1925, returning from the Paris exhibition, Fortunato Depero introduced Le Corbusier to the Italian public (Doodran 1988, 51). See also P. M. Bardi, 1934, 'Le Corbusier a Roma.' Quadrante 13 (May): 5 and for a detailed account of the Swiss architect's work in relation to Italian architecture, especially the tensistruttura, see Guido Fiorni, 1933, 'Linventore Le Corbusier poeta-archietto della presente civilità macchinista.' Architettura 2, no.6 (June): 357-64.

52. Beginning in 1926, a four-part series of articles appeared in the cultural review Rassegna italiana, proclaiming the existence of a 'new spirit' in architecture. The principal elements of Le Corbusier's new architectural language articulated in his seminal text were: pillars, the roof as symbolic garden, open plan, ribbon windows and a free-standing façade. Gropius instead insisted on the principles of standardization and rationalization in architecture, through the use of similar designs and new materials.

53. See, for example, Alberto Sartoris, 1933, 'Surrealismo e funzionalismo.' Quadrante 1, no. 4 (August): 29-30 and Alberto Sartoris, 1933, 'Per un'architettura integrale.' Ibid., no. 7 (November): 8-9. Sartoris linked the lyrical element of artistic creation with individual daily necessities. 
54. 'al fabbricato delle turbine, nudo, elementare, senza ombre, si innesta l'edificio quadri, a solette sovrapposte e sporgenti tutto all'intorno così da alternare ritmicamente fasce orizzaontali di luce e di ombre'.

55. http://dialecticsofmodernity.manchester.ac.uk/essay/380

56. Libera-Minucci, Introduzione, in I Esposizione italiana di architettura razionale, catalogue of the exhibition, De Alberti, Rome, 1928, now in Patetta (1972, 127-28).

57. For a clear assessment of the second MIAR exhibition and reactions to it, see Kallis $(2014,63-66)$ and Etlin (1991, 385).

58. http://dialecticsofmodernity.manchester.ac.uk/tag/classical-tradition

59. http://dialecticsofmodernity.manchester.ac.uk/essay/492

60. The Mostra della Rivoluzione was directed by Libera and De Renzi, supported by Piacentini and supervised by Dino Alfieri. It ran for two years, from 28 October 1932 to 28 October 1934, and enjoyed extraordinary success, with a total of $3,700,000$ visitors.

61. http://dialecticsofmodernity.manchester.ac.uk/essay/466; http://dialecticsofmodernity.manchester.ac.uk/artefact/23; http://dialecticsofmodernity.manchester.ac.uk/essay/492

62. On the arguments within the rationalist front Bardi (Quadrante), Terragni, and Pagano, see Patetta (1972, 119-51) and Ciucci (2002 [1989], 129-51), while on those within the monumentalists front (Piacentini and Ojetti), see (Patetta 1972, 315-33).

63. P. M. Bardi, 1933, 'La Rivoluzione “Consegna” di Mussolini.' Quadrante 1, no. 4 (May): 1.

64. http://dialecticsofmodernity.manchester.ac.uk/essay/495

65. Vinicio Paladini, 1933, 'Imborghesimento del razionalismo.' Quadrante 1 , no. 3 (July): 36.

66. On the relationship between architects and Mussolini and on his close scrutiny of State-commissioned projects, see Nicoloso (2008, 79-80, especially Chaps. 6 and 7).

67. http://dialecticsofmodernity.manchester.ac.uk/artefact/41; http://dialecticsofmodernity.manchester.ac.uk/essay/497; http://dialecticsofmodernity.manchester.ac.uk/essay/494

68. Giò Ponti designed the Maths building, Pagano the Physics building, and Piacentini the Rectorate.

69. http://dialecticsofmodernity.manchester.ac.uk/essay/522

70. Filliàs 'Futurismo e Fascismo' was published in April 1929 in La Città futurista (Patetta 1972, 257-61). He considered Futurism and archi- 
tecture to be the highest forms of artistic expression, and hence de facto as State art. Bontempelli, however, was critical of Futurist architecture, seeing it as being concerned with the aestheticization of forms rather than with the function these have to perform (January 1934, L'avventura novecentista, 328-39).

71. As early as the 1928 Turin Expo, the Futurist pavilion provided a dedicated space for Futurist architecture.

72. http://dialecticsofmodernity.manchester.ac.uk/essay/407

73. The theme for La Spezia was Le vie del mare e del cielo and the two mosaics were entitled Le communicazioni terrestri e marittime (Fillia) and Le communicazioni telegrafiche, telefoniche e aeree (Prampolini), while in 1938 in Palermo the theme for Benedetta Cappa's frescos is the Vie delle communicazioni di terra, di mare e d'aria, telegrafiche e radiofoniche, and for Tato (Guglielmo Sansoni) youth and work.

74. http://dialecticsofmodernity.manchester.ac.uk/essay/396

75. http://dialecticsofmodernity.manchester.ac.uk/essay/401

76. Sironi et al. (1933), in Sironi, Scritti, 156. Sironi, 1934, 'Manifesto.' L'Ambrosiano (26 July), in Scritti, 173-75.

77. Anonymous, 1933, 'La casa del sabato per gli sposi.' Casabella 11, no. 6 (June): 10-11 in Trivellin (1996, 73, also for the attribution of the article), Arch. R. Camus, 1933, 'La casa del sabato degli sposi.' Edilizia moderna XI-XII, no. 10-11 (August-December): 24-27, and F. T. Marinetti, 1933, 'Premessa alla Quinta Triennale di Milano'. In Catalogo Ufficiale (Milan: Ceschina, 54).

78. On 6 August 1933 in L'Italia letteraria Edoardo Persico was fairly critical of the Casa studio, but praised the Casa del sabato for its European take on stylistic innovation, 'Alla Triennale. Gli architetti italiani.' 4, no. 32: 4.

79. On the progressive marginalization of architects from the architettura di Stato, see De Seta (1998, 81-91).

80. http://dialecticsofmodernity.manchester.ac.uk/essay/522

81. Giovanni Michelucci was a highly regarded professor of architecture at Florence University; for further details on the competition, see Chap 7.

82. From 1933, Casabella was co-directed by Persico and Pagano, who was also editor-in-chief of Domus.

83. http://dialecticsofmodernity.manchester.ac.uk/essay/480

84. On the nuances of the understanding of monumentalism by Piacentini, Ojetti and Pagano, see Nicoloso (2008, 61-63).

85. http://dialecticsofmodernity.manchester.ac.uk/tag/sacralization 
86. For an analysis of the relationship between Terragni and Bontempelli, see Storchi (2007, 237-40), and especially Storchi (2012) on the cultural exchanges and working dynamics between Bontempelli-Bardi's Quadrante and the worlds of literature and architecture, and Chap. 5 for a fuller discussion.

87. http://dialecticsofmodernity.manchester.ac.uk/essay/405

88. http://dialecticsofmodernity.manchester.ac.uk/essay/427

89. http://dialecticsofmodernity.manchester.ac.uk/essay/491

90. Writing in Casabella, Pagano is critical of monumentalism because he deems it an unsuitable language for portraying modern society. In a later article, 'Chi si ferma è perduto', he looks back at Palazzo Gualino, thought at the time to represent an 'absurd nakedness', but now the mark of modern building (1938, Casabella-Costruzioni, no. 128, (August), in De Seta 2008, 45).

Open Access This chapter is licensed under the terms of the Creative Commons Attribution 4.0 International License (http://creativecommons.org/ licenses/by/4.0/), which permits use, sharing, adaptation, distribution and reproduction in any medium or format, as long as you give appropriate credit to the original author(s) and the source, provide a link to the Creative Commons licence and indicate if changes were made.

The images or other third party material in this chapter are included in the chapter's Creative Commons licence, unless indicated otherwise in a credit line to the material. If material is not included in the chapter's Creative Commons licence and your intended use is not permitted by statutory regulation or exceeds the permitted use, you will need to obtain permission directly from the copyright holder.

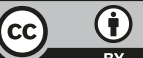

